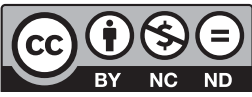

Estudos Teológicos foi licenciado com uma Licença Creative Commons Atribuição - NãoComercial - SemDerivados 3.0 Não Adaptada

http://dx.doi.org/10.22351/et.v60i3.3804

\title{
A missão ad Gentes em torno da renovação do Vaticano II $^{1}$
}

The ad gentes mission around the renewal of the Second Vatican

\section{Nadi Maria de Almeida Agenor Brighenti ${ }^{3}$}

Resumo: O artigo faz uma abordagem teológico-pastoral da missão ad gentes antes, durante e depois do Concílio Vaticano II, a partir de estudos bibliográficos de autores que se debruçaram sobre o tema. $\mathrm{O}$ texto tem dois momentos. $\mathrm{O}$ primeiro apresenta a situação da missão antes e no contexto do Vaticano II. O segundo enfoca a missão no contexto da implementação da renovação conciliar. $\mathrm{O}$ estudo mostra que o conceito de missão foi mal entendido no período da cristandade, levando a um desvio da atividade missionária na igreja da época. O Concílio, em sua volta às fontes, corrigiu equívocos e colocou as bases de uma atualizada teologia da missão, em sintonia com o espírito da proposta evangélica.

Palavras-chave: Vaticano II. Igreja. Missão ad gentes. Evangelização.

Abstract: The article makes a theological-pastoral approach to the mission ad gentes before, during and after the Second Vatican Council, based on bibliographical studies of authors who have researched and written about the theme. The text is structured in two moments. The first moment presents the mission situation before and in the renewal context of Second Vatican Council. The second moment focuses on mission in the context of implementing the Conciliar. The study shows that the concept of mission was misunderstood in the period of Christendom, leading to a deviation of missionary activity in the Church of the time. The Council, in its return to the sources, corrected misunderstandings and laid the foundations of an up-to-date mission theology, in tune with the spirit of the gospel proposal.

Keywords: Second Vatican. Church. Ad gentes mission. Evangelization.

1 O artigo foi recebido em 27 de agosto de 2019 e aprovado em 21 de novembro de 2020 com base nas avaliações dos pareceristas ad hoc.

2 Mestre. Pontifícia Universidade Católica do Paraná - PUCPR/CAPES. E-mail: nadinadimaria@gmail.com

3 Doutor. Pontifícia Universidade Católica do Paraná - PUCPR. E-mail: agenor.brighenti@gmail.com 


\section{Introdução}

O notável missiólogo sul-africano David Bosch, em sua obra seminal intitulada Missão transformadora, declarou: "Missão é o sim de Deus para o mundo"4. O Concílio Vaticano II apresenta uma igreja que deseja ser solidária com a humanidade inserida no mundo, desejando que toda a sua vida seja impregnada e renovada pelo vigor e pelo espírito missionário da Trindade. E anseia que as sementes sejam lançadas, brotem, cresçam e produzam frutos.

Nessa perspectiva, propomo-nos, aqui, fazer uma abordagem da missão ad gentes no contexto dos 50 anos do Concílio Vaticano II, colocando em relevo a mudança na maneira de ver e fazer missão, fruto deste kairós. Trata-se de uma reflexão teológico-pastoral da missão ad gentes antes, durante e depois do Vaticano II, a partir de estudos bibliográficos de autores que se debruçaram sobre o tema. O texto tem dois momentos. O primeiro apresenta a situação da missão antes e no contexto do Vaticano II. O segundo enfoca a missão no contexto da implementação da renovação conciliar, em especial a reviravolta e os impactos da nova postura na missão ad gentes, como o respeito às culturas, povos e religiões.

Com a renovação do Vaticano II, novos caminhos e maneiras de fazer missão são propostos, de modo que a igreja não perca de vista sua natureza missionária, a serviço do reino de Deus no mundo.

\section{A missão antes e durante o Vaticano II}

No imediato pré-concílio, a igreja estava vivendo um tempo de profundas transformações, interpelada de dentro e de fora em direção a uma urgente renovação. Segundo Souza, ela sente-se desafiada a um novo ardor e impulso missionário, desejando envolver todo o povo de Deus em torno da missão, de modo que o reino de Deus atinja todos os povos 5 .

\section{A missão antes da renovação do Vaticano II}

Antes do Concílio Vaticano II a visão de missão havia perdido seu significado e "poder". Segundo Ukpong, a visão que inspirou os grandes movimentos missionários foi estreitamente eclesiocêntrica, cujo objetivo é a expansão da igreja e o desejo de salvar almas. A missão não só tinha problemas, como havia se tornado um problema em si mesma. ${ }^{6}$ Havia muitos questionamentos sobre a necessidade e o modo de se

4 BOSCH, David. Missão transformadora: mudanças de paradigma na teologia da missão. Trad. Geraldo Korndörfer e Luís M. Sander. São Leopoldo: Sinodal, 2002. p. 28.

5 Cf. SOUZA, Ney. Contexto e desenvolvimento histórico do Concilio Vaticano II. Revista de Teologia e Cultura, n. 02, p. 1-36, out./nov./dez. 2005.

6 Cf. UKPONG, Justin. Contemporary Theological Models of Mission: Analysis and critique. AFER, n. 10, p. $162-164,1983$. 
fazer missão e, mesmo após o Concilio Vaticano II, houve ainda objeções e se levantavam vozes criticando a missão de caráter eurocêntrico e eclesiocêntrico. ${ }^{7}$

Segundo Bevans e Schroeder, as missões eram conduzidas principalmente pelo clero que dirigia escolas, hospitais e orfanatos. A atividade missionária tendia a ser entendida em livrar os povos das garras do diabo. As religiões tradicionais eram consideradas adorações satânicas. Em resumo, a visão de missão pré-Vaticano II estava motivada em salvar almas e implantar a igreja, pois "fora da Igreja não há salvação"s.

Reinava o modelo de missão expansionista, levada a cabo por uma igreja com a pretensão de possuir a verdade. A encíclica de Benedito XV - Maximum Illud, publicada em 1919 - sobre a propagação da fé católica no mundo foi a primeira encíclica missionária. Entretanto, segundo Bevans e Schroeder, é um documento de embasamento teológico limitado, dado que o único objetivo é a conversão. ${ }^{9}$

No entanto, havia vozes proféticas e atitudes que não condiziam nem se encaixavam naquele modelo de missão. Bevans e Schroeder afirmam que o papa Pio XI promoveu a formação missionária do clero e do bispo local e foi uma voz profética insistindo que os cristãos chineses, por exemplo, não deveriam tornar-se uma sociedade estrangeira e que os missionários se inserissem e se encarnassem no contexto da missão. ${ }^{10}$ Incentivou-os até, se possível, que se naturalizassem para ficar mais próximos possível da cultura chinesa. ${ }^{11}$

Com a Segunda Guerra Mundial a Europa perdeu muitos seminaristas missionários e as colônias voltaram seu interesse para missionários de língua inglesa. Os Estados Unidos viram sua hora missionária para além dos mares. ${ }^{12}$ Congregações femininas e masculinas começaram a enviar missionários e foram fundadas revistas missionárias católicas, divulgando a vida missionária além-fronteiras. Por exemplo, o

7 Em 1970, Paul Verghese, da Igreja Síria Ortodoxa na Índia, disse que a missão era "a maior inimiga do Evangelho". Um ano depois um teólogo da Ásia, Emérito Nacpil (1971) faz uma crítica aos missionários - "o melhor serviço missionário que um missionário dentro do presente sistema pode dar para Ásia hoje é voltar para sua casa”. Na América Latina, levantaram-se semelhantes vozes como no Simpósio de Antropólogos em Barbados, em 1971, que em sua declaração dizem que a atividade missionária era apenas um pretexto para continuar com o colonialismo, explorando e alienando os povos nativos da América do Sul. E concluem que "por interesse dos povos indígenas e para sua integridade moral, que as Igrejas suspendessem toda e qualquer atividade missionária" (BEAVER, Pierce (Ed.). The Gospel and frontier people. Chicago: The William Carey Library, 1973. p. 369-375). Ainda vozes na África como em 1974, na assembleia de todas as igrejas em Lusaka, Zâmbia: "está claro que nós nunca seremos autossuficientes até que mantemos estas estruturas que herdamos dos missionários". Cf. CANON BURGESS THE MORATORIUM: The search for self-reliance and authenticity. All Africa Conference of Churches Bulletin, v. VII, n. 3, p. 19-42, 1974.

8 Cf. BEVANS, Steven B.; SCHROEDER Robert P. Constants in context: A theology of mission for today. Maryknoll, New York: Orbis books, 2004.

9 Cf. BEVANS; SCHROEDER, 2004.

${ }^{10}$ O papa Pio XI pessoalmente consagrou os seis primeiros bispos chineses em 1926, um japonês em 1927 e um do Vietnã em 1933. Ele instituiu a celebração do Dia Mundial das Missões e nomeou Francisco Xavier e Teresa de Lisieux patronos da missão. Cf. BEVANS; SCHROEDER, 2004.

11 BEVANS; SCHROEDER, 2004.

12 Os Estados Unidos enviaram missionários, a maioria deles, para a missão na China. 
“Centro missionário Maryknoll, com programas educacionais de 1920 a 1950, ajudou a ir moldando o entendimento missionário para os católicos nos Estados Unidos"13.

Bevans e Schroeder afirmam que em 1931, com a Encíclica Quadragesimo Anno, de Pio XI, há um impulso dos movimentos da Ação Católica, que chamou os leigos e leigas católicos a assumirem a causa da crise econômica e social, que surge também nos Estados Unidos. Nessa época a maioria dos missionários era conformada de celibatários: padres, irmãos e irmãs, com exceção do Movimento Internacional de Mulheres, fundado na Holanda e estabelecido oficialmente nos Estados Unidos em 1944, assim como de alguns leigos que trabalhavam para as congregações religiosas no campo de missão e que também contribuíam com o trabalho missionário. Nessa perspectiva, a Encíclica Mystici Corporis (1943), seguida de outras duas encíclicas missionárias, Evangelii Praecones (1951) e Fidei Donum (1957), as três de Pio XII, encorajam os leigos católicos a se envolverem em ações sociais e missão. ${ }^{14}$

Em resposta à Fidei Donum, duas organizações missionárias de leigos surgiram nos Estados Unidos: a Women Volunteers for África e a Lay Mission Helpers of Los Angeles. ${ }^{15}$ Fruto delas, em 1958, já havia 96 leigos missionários além-fronteiras e houve a primeira conferência católica de missionários leigos em Chicago. ${ }^{16}$

Nessa época, também os missionários protestantes aumentaram suas atividades na América Latina, motivada pela igreja dos Estados Unidos. Bevans e Schroeder lembram ainda que outra preocupação católica do contexto imediato anterior ao Vaticano II era que Cuba havia se tornado comunista e havia medo que o comunismo se estendesse a outros países. Mencionam igualmente Charles de Foucault, um ex-monge trapista, que fez trabalhos voluntários para uma comunidade pobre em Nazaré e Jerusalém. Praticou a caridade, a hospitalidade, libertou escravos e curou os feridos da batalha entre árabes e franceses. Segundo os autores, "Foucault se tornou modelo para missão do século vinte, um modelo de presença"17.

Podemos ainda destacar o movimento dos padres operários, fundado pelo Cardeal Emmanuel Sühard, que se inspirou na vida de Foucault, marcando presença cristã onde os trabalhadores estavam, nas fábricas e trabalhos portuários. Um movimento que sofreu pela incompreensão, mas que representou um "modelo alternativo para missão", pelo testemunho de presença entre os pobres trabalhadores. ${ }^{18}$

Enfim, no contexto imediato anterior ao Concílio Vaticano II havia vozes e ações se levantando contra o modelo colonialista de missão, que com certeza foram

${ }^{13}$ BEVANS; SCHROEDER, 2004, p. 245-246.

${ }^{14}$ Cf. BEVANS; SCHROEDER, 2004.

15 "Mulheres Voluntárias para África" e "Missão de leigos ajudantes de Los Angeles".

${ }^{16}$ BEVANS; SCHROEDER, 2004, p. 248.

17 BEVANS; SCHROEDER 2004, p. 248. Após a morte de Foucault em 1916, ele se tornou conhecido também por meio de seus escritos e deu-se origem a duas congregações por meio das regras que deixou escritas: a Fraternidade dos Pequenos Irmãos de Jesus (1933) e a Fraternidade das Irmãzinhas de Jesus (1936). Essas duas comunidades religiosas continuam a viver esse modelo de presença cristã em uma ampla variedade de contextos. Por exemplo, no Brasil, fizeram importantes trabalhos missionários, renovando a presença missionária católica, entre indígenas e periferias urbanas.

${ }^{18}$ BEVANS; SCHROEDER, 2004, p. 249. 
raios de luzes na reflexão e construção dos esquemas do Decreto Ad Gentes do Concílio. Como vimos, a visão de missão de Pio XI manifestada em suas encíclicas, assim como de Pio XII; o exemplo de missão como presença e inserção de Foucault; a Ação Católica e os movimentos de leigos missionários que abrem as portas para iniciativas de leigos e leigas na missão da igreja; o movimento dos padres operários e tantas outras ações que se fizeram presentes na época, foram com certeza janelas de inspiração para o papa João XXIII e os padres conciliares com a mesma visão de igreja e de missão que iluminou os trabalhos do Concílio Vaticano II.

\section{A missão no contexto do Vaticano II}

"Missão aos povos" foi tema de debate no Concílio Vaticano II. Raschietti ressalta que o papa João XXIII "convida a Igreja a olhar os sinais dos tempos, a abrir-se a um novo pentecostes", exigindo dela uma "profunda compreensão, com sincera admiração e com franco propósito não de conquistar, mas de valorizar o mundo; não de condená-lo, mas de confortá-lo e salvá-1o"19.

Havia uma grande movimentação em torno da práxis missionária quando o papa João XXIII anunciou o Concílio. O momento estava permeado de crises e tensões que refletiam as práticas da missão católica da época. A comissão preparatória do documento sobre a missão deveria ter em mente a reviravolta que estava se dando na atividade missionária naquele momento histórico. Deveria ser protagonista de um documento que representasse suficientemente o contexto e as novas tendências teológicas de então. A imagem da comunhão trinitária deveria ser a inspiração e o convite a uma missão pautada pelo diálogo, a presença gratuita e o testemunho.

Bevans e Schroeder destacam situações tais como a juventude que questiona a autoridade e tradições de muitas colônias que buscavam sua independência ou já se haviam tornado independentes, bom como a visão otimista da humanidade e a secularização. A igreja estava vivendo um momento que clamava por mudanças radicais. O modelo antigo de missão já não cabia no contexto moderno e o papa e os padres conciliares estavam cientes da situação. ${ }^{20}$

Brighenti fala do Vaticano II como um momento de mudanças profundas e desafiadoras, de "continuidade e descontinuidade" [...] de reforma, "ad intra $e$ ad extra", de uma reforma "em todos os campos". ${ }^{21}$ Era preciso coragem e audácia para se abrir ao diálogo com o mundo moderno sem romper com a tradição, mas fazendo uma "profunda reforma da Igreja em todos os campos"22. O conceito de missão não podia mais deixar de lado a relação intrínseca da igreja com o mundo. No contexto

19 RASCHIETTI, Estevão. Ad Gentes: texto e comentário. São Paulo: Paulinas, 2011. p. 10-11, citando Enchiridion Vaticanum, 23, 190.

${ }^{20}$ BEVANS; SCHROEDER, 2004, registram que 823 bispos participantes do Concílio vinham de áreas de missão da África, Ásia e Oceania.

${ }^{21}$ BRIGHENTI, Agenor. Em que o Vaticano II mudou a Igreja. São Paulo: Paulinas, 2016. p. 7-8, 11.

${ }^{22}$ BAKKER, N. J. O conceito de "missão": sua história e seu significado na visão pastoral do Papa Francisco. $R E B$, Petrópolis, ano 74, n. 294, p. 453, abr./jun. 2014. 
do Concílio, o modelo de missão colonialista, expansionista e eclesiocêntrica estava em crise e em fase de decadência. A imagem de igreja hierarquizante, que dominava a eclesiologia também deveria ser reformada.

A renovação que o Concílio Vaticano II traz para missão da igreja, nas palavras do papa João XXIII, foi abrir-se a um "aggiornamento", que segundo Chia significa que a "Igreja precisava se atualizar e colocar-se em dia com a evolução da sociedade". Para isso, era necessário abrir-se ao diálogo, "se a Igreja quisesse se relacionar e integrar-se com outras entidades e comunidades sociais" ${ }^{23}$. Brighenti aporta que o Vaticano II trouxe transformações profundas, pontuais e renovação em todos os campos, "na teologia e nas práticas, na auto-compreensão [sic] da Igreja e em seu posicionamento no mundo, seja com relação às ciências, seja com as Igrejas e às religiões". Trata-se de uma "Igreja mais solidária com a humanidade, em especial com os pobres e os que sofrem" 24 .

\section{A missão na renovação do Vaticano II}

Felizmente, o Vaticano II traria uma nova visão de missão, resgatando seu verdadeiro significado e a maneira de levá-la a cabo. Destacou de maneira específica o tema da missão aos povos "ad gentes", colocando no seio do próprio ser da igreja o caráter missionário. A igreja está a serviço da missão do reino de Deus. É a visão de igreja que permeia não somente o Decreto $A d$ Gentes, mas também a maior parte dos documentos conciliares. ${ }^{25}$

\section{Um concílio que mudou a igreja}

O Concílio Vaticano II foi um verdadeiro kairós para a igreja. Antes de tudo, em sua denominada "volta às fontes" bíblicas e patrísticas, rompeu com o eclesiocentrismo e o cristomonismo, que caracterizou a autoconsciência da igreja no largo período de cristandade, com consequências concretas para a missão. Isso significou uma reviravolta na vida da igreja como um todo, obrigando-nos a falar de um "antes" e um "depois" do Vaticano II. Sua recepção nas igrejas locais, entretanto, é um processo marcado por avanços, estancamentos e retrocessos.

Mudança fundamental do Concílio foi à superação do eclesiocentrismo então reinante na igreja há mais de um milênio, por meio do resgate do reino de Deus na autocompreensão da igreja. Põe-se em evidência que o Reino é mais amplo do que a igreja. Essa é uma de suas mediações, ainda que privilegiada, dado que dispõe dos sacramentos e da Palavra revelada, mas não a única. Enquanto servidora do Reino, em consequência, o raio de atuação da igreja vai além de suas próprias fronteiras.

${ }^{23}$ CHIA, Edmond. De 'Missio ad Gentes' para 'Missio inter Gentes'. In: BEVANS, S. B. (Org.). A century of catholic mission: Roman Catholic Missiology 1910 to the Present. Oxford: Regnum Books International, 2013. p. 216.

${ }^{24}$ BRIGHENTI, 2016, p. 7.

${ }^{25}$ Por exemplo, os documentos que vêm citados no parágrafo seguinte: LG, GS, NA e DH. 
A igreja existe para tornar presente o reino de Deus no mundo, em diálogo com as demais igrejas, religiões e com todas as pessoas de boa vontade. Há obras do Espírito para além da presença da igreja. Antes do missionário sempre chega o Espírito Santo, "que sopra onde, quando e em quem ele quer", diz o Concílio. O reino de Deus descentra a igreja de si mesma, de suas questões internas, e leva-a a abraçar as grandes causas da humanidade, pois: "as alegrias e as esperanças, as tristezas e as angústias dos homens de hoje, sobretudo dos pobres e de todos os que sofrem, são as alegrias e as esperanças, as tristezas e as angústias dos discípulos de Cristo" (GS 1). Mas há dificuldades em ser consequente com essa postura. No largo processo de "involução eclesial" que se abateu sobre a igreja da década de 1990 até à eleição do papa Francisco, que resgatou o Vaticano II, uma "Igreja autorreferencial"26, absorvedora em lugar de servidora do reino de Deus, tem sido uma das expressões do distanciamento da renovação do Concílio.

Mudança não menor foi a superação do cristomonismo. Antes do Vaticano II, a eclesiologia estava fundada em uma cristologia docetista, pois, ao identificar-se com o Corpo do Cristo Glorioso e Ressuscitado, historicamente, tende a divinizar a instituição eclesial e a reduzi-la aos cabeças desse Corpo, que são os clérigos. Y. Congar iria falar de uma eclesiologia que se confunde com uma "hierarcologia". Leigo é aquele que não é clérigo e, portanto, é um destinatário da missão, quando não um consumidor dos sacramentos que a hierarquia dispensa ou, no máximo, uma extensão de seu braço, numa perspectiva de cooperação com seu ministério. Ao resgatar sua matriz trinitária - "a Igreja é o corpo dos três" (o corpo do Pai, do Filho e do Espírito Santo, dizia São Basílio) -, a igreja no Vaticano II vai autocompreender-se como "comunhão" (koinonía): uma única classe de cristãos, os batizados, entre os quais, a exemplo do que acontece no interior da Trindade, na diversidade de ministérios, "há uma radical igualdade em dignidade" entre todos. Em consequência, o sujeito eclesial, em lugar da hierarquia, passa a ser toda a comunidade eclesial ("a Igreja somos nós”) e, portanto, também ela é o sujeito da missão, chamada a fazer chegar a salvação de Jesus Cristo a todo o gênero humano. Com isso, a finalidade da missão deixa de ser a implantação da igreja, para constituir-se no testemunho e no anúncio gratuito do Evangelho, cuja acolhida redunda na comunhão de todos os seres humanos com Deus e com os demais e a Criação. Também nesse particular a dificuldade tem sido passar do binômio clero-leigos a comunidade-ministérios, com a volta do clericalismo e a própria clericalização do laicato. A sinodalidade funda-se na comunhão de todos os batizados e batizadas e pressupõe o exercício do sensus fidelium, base sobre a qual se apoia a igreja como povo de Deus. ${ }^{27}$

Outra mudança profunda do Vaticano II com consequências para a missão foi a compreensão da evangelização como humanização. Com a encarnação de Jesus e sua ressurreição, o divino e o humano se encontram e se unem indissoluvelmente, sem

${ }^{26}$ VELASCO, Rufino. A Igreja de Jesus: processo histórico da consciência eclesial. Petrópolis: Vozes, 1996. p. 429.

27 Sensus fidelium, princípio teológico que reconhece a conaturalidade do cristão com as coisas da fé (sensus fidei) e que habilita o conjunto dos fiéis cristãos a não se enganar no ato da fé (cf. LG 12). 
oposição ou contradição: quanto mais divino, mais humano e, quanto mais humano, mais divino. Consequentemente, o cristianismo não propõe nada mais à humanidade que sermos plenamente humanos. A proposta cristã não é confessionalista, válida só para os cristãos. A mensagem cristã é sempre boa nova para qualquer religião, cultura ou pessoa. Os valores cristãos apontam para a plenitude do humano, para uma "vida em abundância" (Jo 10.11), já a partir desta vida. Vida em plenitude para a "pessoa inteira e todas as pessoas" (Populorum Progressio 14). A mensagem cristã não tolhe o humano, antes o potencia, redimensiona e plenifica. Não é ameaça à autonomia e à liberdade. Não é alienação ou fuga, seja do corpo, seja da concretude da história. O Deus judaico-cristão não é um rival do ser humano, antes fonte de vida em plenitude. Nesse particular, a dificuldade na recepção do Concílio tem sido a superação de espiritualismos desencarnados e a interação ou presença da igreja no âmbito da sociedade, em perspectiva profética e transformadora. Em lugar de uma missão consequente com os desafios que brotam de um contexto que clama por compromisso, não raro se apela a providencialismos e milagrismos, entre a magia e o esoterismo. ${ }^{28}$

Também não se pode deixar de mencionar outra mudança do Vaticano II, com consequências diretas para a missão, que é a afirmação que a igreja existe para a salvação do mundo. A igreja, enquanto "gérmen e princípio" do reino de Deus na concretude da história, realiza sua missão no mundo e para o mundo. Segundo o Vaticano II, a igreja está no mundo e existe para a salvação do mundo. Cabe-lhe, portanto, ser uma presença de serviço, numa postura de diálogo, buscando juntamente com toda a humanidade, respostas ao desafio da edificação de um mundo justo e solidário para todos, segundo os ideais do reino de Deus. Dado que Deus enviou seu Filho para salvar o mundo, a igreja é mediação da salvação de Jesus Cristo no mundo, na medida em que, com sua ação evangelizadora, o assume para redimi-lo. Consequentemente, o mundo não é indiferente ao cristão, exterior e separado de uma suposta vocação "celestial" dos cristãos, pois é no mundo que acontece a salvação. Dado que, pela graça divina, a realidade do mundo está aberta a Deus, toda tarefa de humanização converge para Deus. Consequentemente, só quando a igreja se encarna no mundo, torna-se sacramento de salvação do mundo. No processo de recepção do Concílio, neste particular, há dificuldade de diálogo com o mundo atual, que contribui para a criação por parte de certos segmentos da igreja de uma "subcultura eclesiástica", um mundo dentro do mundo, a típica postura de seita ou gueto, quando os cristãos têm como vocação "ser luz do mundo" (Mt 5.14) e "fermento na massa" (Mt 13.33).

\section{A nova teologia da missão}

Segundo Bevans e Schroeder, a imagem de igreja que o Concílio apresenta na Lumen Gentium (LG) é de uma igreja povo de Deus, que caminha buscando a realização do reino de Deus. Com a Gaudium et Spes (GS), o Concílio a chama a dialogar com a realidade global. Com o Decreto Ad Gentes (AG) introduz um novo entendi-

${ }^{28}$ Cf. BRIGHENTI, 2012, p. 124-125. 
mento em relação às religiões, reconhecendo valores e elementos religiosos como preparação para receber o Evangelho. Com a Declaração Nostra Aetate (NA), com prudência e caridade, em diálogo e colaboração com membros de outras religiões, o cristianismo é desafiado a testemunhar sua fé. Com isso, abre-se o debate teológico sobre a salvação nas diferentes religiões e o papel da igreja nesse contexto. Com a Declaração Dignitatis Humanae (DH), reconhecem-se o livre-arbítrio de todas as pessoas em buscar Deus e a verdade sem coerção. ${ }^{29}$

Em resumo, o Concílio supera uma atitude colonialista de missão e volta aos seus fundamentos bíblicos e teológicos, inaugurando um novo jeito de ser igreja e de fazer missão. Volta às raízes, às fontes da igreja primitiva, para uma reflexão teológica da ação missionária a partir da Trindade..$^{30}$ Maestro assinala que "o desafio da globalização para o missionário é trabalhar para que exista uma verdadeira comunhão com as pessoas e nações do mundo". Para ele, "o grande desafio (da Igreja missionária) é o de humanizar a globalização"31. Nesse sentido, num contexto globalizado, evangelizar tem a ver com a vida das pessoas, com a busca de paz, da justiça social, do respeito e o diálogo com religiões. No decreto $A d$ Gentes, a missão é compreendida como testemunho de vida, diálogo e presença de caridade..$^{32}$

A nova visão de "missão aos povos", trazida pelo Concílio Vaticano II, convida a igreja a olhar e ler os sinais dos tempos. O impulso à abertura missionária que o Concílio dá à igreja ilumina e convida a tomar consciência de sua missão evangelizadora no mundo. Para Paulo Suess, "o Concílio iniciou processos que livraram a missão da fixação a territórios geográficos e fizeram a Igreja descobrir sua natureza missionária" ${ }^{33}$.

O Vaticano II apresenta a missão como um dom que brota do amor misericordioso do Pai, do Filho e do Espírito para com a humanidade. Brota da Trindade, que encarrega a igreja a continuar no mundo a missão de amor para com todos os povos e nações, sem perder de vista o foco da preocupação divina com os últimos e excluídos, os privilegiados na missão de Jesus. O Mestre afirma ter sido ungido para "pregar o evangelho aos pobres", para "libertar os presos, recuperar a vista aos cegos, restituir a liberdade aos oprimidos e anunciar o tempo da graça do Senhor" (Lc 4.18). Por isso é preciso focar em Jesus, o missionário do Pai e modelo ideal para missão da igreja no mundo.

${ }^{29}$ Cf. BEVANS; SCHROEDER, 2004.

${ }^{30}$ Essa visão trouxe uma maneira respeitosa, acolhedora e diferente de valorização da maneira de aproximação dos povos, culturas e religiões.

${ }^{31}$ MAESTRO, Luís M. Missão ‘ad gentes' e globalização: desafio para a Igreja no Brasil. Revista Eclesiástica Brasileira - REB, São Paulo, v. 14, n. 56, p. 104-105, 2006. “A globalização trouxe os avanços na atual sociedade globalizada (tecnologias, sistema jurídico e financeiro, sistema de controle social, e outros), mas em meio a deficiências gritantes em relação ao direito comum das pessoas e dos povos, bem como em relação ao que permite a cada um viver a verdadeira felicidade" (Cf. DOCUMENTO 105 DA CNBB. Disponível em: <https://spirandiopadre.wordpress.com/2016/07/16/cristaos-leigas-e-leigos-na-igreja-ena-sociedade-sal-da-terra-e-luz-do-mundo-mateus-513-14-cnbb-documento-105/>).

32 PAULO VI. Decreto do Concílio Vaticano II: Ad Gentes. Sobre a atividade missionária da Igreja (1965). In: Compêndio do Vaticano II. Petrópolis: Vozes, 2000. n. 10-12.

33 SUESS, Paulo. Introdução à teologia da missão: convocar e enviar: servos e testemunhas do Reino. Petrópolis: Vozes, 2007. p. 118. 


\section{O significado do Vaticano II para a missão}

O Concílio Vaticano II convida a igreja não somente a uma reflexão missionária, mas também a uma conversão ${ }^{34}$, a um plano de ação com uma maior abertura, audácia, empenho e dedicação, de seus líderes e de cada cristão, à missão ad gentes. O novo paradigma de missão introduzido pelo Vaticano II é pautado pela abertura e o diálogo com as culturas, com as religiões e com o mundo moderno. Andrade frisa que se trata de um diálogo claro e respeitoso, considerando a pessoa do outro e sua cultura. Chama a atenção que "os documentos do Vaticano II declaram que a Igreja não rejeita nada daquilo que é verdadeiro e santo em outras religiões" e encoraja os católicos a se empenharem no diálogo inter-religioso. Para Andrade, esse novo modo de fazer missão introduzido pelo Vaticano II "podemos chamar 'diálogo"”. No entanto, para dialogar precisamos reduzir ou eliminar todo tipo de preconceitos. ${ }^{35}$

Observa-se que no Vaticano II a urgência da missão da igreja de anunciar o reino de Deus ${ }^{36}$ é cósmica e deve chegar a todos os povos. Trata-se de um grande desafio para a igreja no mundo contemporâneo, onde há a tendência em cada um de pensar em si próprio. O Concílio Vaticano II, no Decreto Ad Gentes, envolve os cristãos num compromisso não só com as comunidades cristãs, mas também com a cultura e a sociedade. Um serviço cujo objetivo é melhorar as condições de vida da pessoa e dos povos e os libertar da fome, ignorância e da escravidão. ${ }^{37}$ Segundo Brighenti, trata-se de uma decisão missionária corajosa, promotora da cultura da vida, que abarca todos os espaços eclesiais e da sociedade autônoma, o que implica abandonar estruturas ultrapassadas. Para o autor, "logo após o Concílio a Igreja teve uma renovada mudança, que causou reviravoltas". Entretanto, nem todos acolheram as propostas do Concílio com entusiasmo e esperança. De todos os modos, com o Vaticano II temos a proposição de "uma Igreja solidária com a humanidade, em especial com os pobres e os que sofrem, depois de quase cinco séculos na contramão da história do mundo moderno". Finalmente, "no Vaticano II, a Igreja abriu-se ao mundo"38.

Com o Vaticano II, o modo de se fazer missão tomou uma nova perspectiva, atitude e direção. A nova perspectiva de igreja, afirmada pelo Concílio, trouxe uma passagem radical de uma igreja que tinha missões para uma igreja que vive sua nature-

${ }^{34}$ Nos dias de hoje, o papa Francisco "propõe um novo modelo, denominado de pastoral de conversão missionária". Ver BRIGHENTI, Agenor. Concílio Vaticano II: batalha perdida ou esperança renovada? São Paulo: Paulinas, 2015. p. 280-302.

${ }^{35}$ ANDRADE, Joachin. Novo paradigma da missão na visão antropológica. In: LABONTÉ, G.; ANDRADE, Joachin (Orgs.). Caminho para a missão: fazendo missiologia contextual. Brasília: ABC BSB Gráfica e Editora Ltda, 2008. p. 200, 204.

${ }^{36}$ Anunciar o Reino de justiça, paz, amor e dignidade para todos os seres humanos não significa ensinar e impor doutrinas particulares ou fazer proselitismo, mas entrar em diálogo e unir as forças com outras igrejas, instituições e organismos em favor da vida e do cuidado da criação.

37 Ad Gentes, n. 12.

${ }^{38}$ BRIGHENTI, 2016, p. 7; ver também BRIGHENTI, 2015, p. 280-302. 
za missionária. ${ }^{39}$ Passamos a uma igreja que, movida pelo amor, sai ao encontro. Com isso o Vaticano II lança luzes e impulsiona a igreja a "escancarar" suas portas e sair em missão. Bevans e Schroeder afirmam que a missão na perspectiva conciliar, além de abertura, audácia e coragem, a missão exige humildade, entusiasmo e muito amor. ${ }^{40}$

Buono, por ocasião da jornada do Dia Mundial das Missões, no dia 17 de outubro de 2013, assinalou que existe um unânime consenso em reconhecer que o Concílio Vaticano II mudou a teologia e a prática da missão. Foi um evento extraordinário, tanto eclesial como histórico, de "caráter plenamente universal como nunca tinha acontecido. [...] De tal modo que o Sínodo Extraordinário dos Bispos de 1985 o chamou de 'graça máxima do século XX'". Para o autor, a linguagem da missão no Concílio Vaticano II é trinitária, pois enfatiza a “iniciativa do Pai, fonte de Amor, de Cristo, missionário do Pai, e do Espírito Santo, que torna a Igreja missionária" ${ }^{41}$.

Em suma, o Concílio Vaticano II aspirou revigorar a vida e a missão da igreja em sintonia com os apelos do mundo contemporâneo, ressaltando o caráter missionário da vida cristã, fundamento dinâmico na missão trinitária. Trata-se de um impulso missionário que leva ao ecumenismo e ao diálogo inter-religioso para "que todos sejam um [...], para que o mundo creia que Tu me enviaste" (Jo 17.21). É a igreja abrindo-se à missão ad gentes, se revigorando e se recuperando de seu fechamento e isolamento histórico. Soa o convite para que todos olhem para fora, abram-se ao outro e ao mundo e, com caridade fraterna, retomem o caminho da missão universal.

\section{O Vaticano II e a missão ad gentes}

A nova perspectiva missionária que o Concílio Vaticano II traz é de uma igreja que nasce da missão, dado que sua essência brota da missão da Trindade, em particular de Jesus de Nazaré. Destarte, a missão de cada cristão na igreja não é diferente, é o prolongamento da vida e obra Jesus Cristo. Uma missão que não é obrigação somente de alguns consagrados, mas dever de todo batizado. ${ }^{42} \mathrm{E}$ não se destina a converter, mas a dialogar e servir, a atrair e formar comunidades no seio do povo de Deus. Implica o respeito ao outro, ao diferente, à valorização das culturas, ao reconhecimento da presença e da ação do Verbo presente em toda parte.

Conforme o Vaticano II, o objetivo da missão não é, em primeiro lugar, implantar a igreja, mas "tornar presente o Reino de Deus no mundo"43. Missão não é imposição, mas ir às "gentes” para testemunhar o amor de Deus em meio do seu povo

39 Cf. SUESS, P. Introdução à teologia da missão: convocar e enviar: servos e testemunhas do Reino. Petrópolis: Vozes, 2007.

${ }^{40}$ Cf. BEVANS; SCHROEDER, 2016.

${ }^{41}$ BUONO, Giuseppe. O Vaticano e a missão da Igreja. ZENIT o mundo visto de Roma, 17 out. 2013 , p. 1. Disponível em: <https://pt.zenit.org/articles/o-vaticano-e-a-missao-da-igreja/>.

42 Ad Gentes, n. 11.

43 PAPA FRANCICO. Exortação apostólica do Sumo Pontífice: Evangelii Gaudium: sobre o anúncio do evangelho no mundo atual. 2013. n. 176. 
espalhado pelo mundo inteiro ${ }^{44}$ Por isso o Concílio enfatiza que a missão ad gentes é o cerne da atividade missionária da igreja. Todo cristão é discípulo missionário de Cristo $^{45}$, chamado e enviado para além das fronteiras eclesiais, movido pelo amor, o compromisso, o desprendimento e a fé. Coutinho afirma que "se alguém não souber como deixar, não saberia também como chegar" ${ }^{\prime 4}$.

A missão ad gentes é intrínseca ao ser da igreja. Mesmo que esteja dedicando-se com ardor aos seus trabalhos internos, sempre necessários, deixa de ser a igreja de Jesus Cristo se estiver fechada à graça da renovação missionária que estende o seu amor até os confins da terra. Os que estão "longe" de nossas fronteiras são também irmãos e irmãs, membros da mesma família, e não podem ser ignorados ou deixados em segundo plano, muito menos abandonados. ${ }^{47}$

Paulo Suess destaca que o Decreto Ad Gentes abre a igreja ao ecumenismo ${ }^{48} \mathrm{e}$ ao diálogo inter-religioso, dá espaço aos leigos e leigas na missão e fomenta a cooperação missionária para contribuir com a paz e as culturas. ${ }^{49}$ Nesse sentido, o Decreto Ad Gentes faz um apelo aos presbíteros e agentes de pastoral para que se abram ao espírito ecumênico e se preparem para o diálogo fraterno com os não cristãos. ${ }^{50}$ Para Bosch, a igreja participa da missio $D e i^{51}$, pois o ministério missionário de Jesus - o reino de Deus esperado - está sendo inaugurado entre os humildes e desprezados da sociedade. ${ }^{52}$ Restori, por sua vez, destaca que, após cinquenta anos, o acontecimento do Concílio Vaticano II é um evento atual e relevante para Igreja Católica; é referência para a igreja dialogar com a realidade atual, pois colocou-a em diálogo fraterno com o mundo moderno. ${ }^{53}$

${ }^{44}$ Caberia aqui uma crítica ao número 6 do Decreto AG que menciona os "pregoeiros do Evangelho", que vão pelo mundo pregar o Evangelho e implantar a igreja, colocando essa atitude como fim próprio da atividade missionária. Sabemos que, na realidade, o fim próprio da missão é "tornar presente o Reino de Deus no mundo" e que a igreja cresce como consequência dessa missão e não como fim dela. Entretanto, se entendemos igreja como povo de Deus, que é a visão de igreja do Vaticano II, o sentido e a concepção de implantação de igreja mudam totalmente.

45 A Conferência de Aparecida retomará o tema dos "Discípulos Missionários de Cristo".

${ }^{46}$ COUTINHO, S. R. Missão no contexto do pluralismo religioso. In: LABONTÉ; ANDRADE (Orgs.), 2008, p. 347.

${ }^{47}$ Cf. Ad Gentes, n. 37.

${ }^{48}$ Ad Gentes, n. 11, exorta aos missionários enviados a se familiarizarem com as tradições religiosas presentes no campo de missão. O n. 15 adverte para nutrir entre os neófitos: o espírito ecumênico; promover ação ecumênica, sem ódio e rivalidade; incentivar cooperações em questões sociais e técnicas, culturais e religiosas.

${ }^{49}$ Cf. SUESS, 2007.

${ }^{50}$ Cf. Ad Gentes, n. 16.

${ }^{51}$ Barth (1968) afirma que "na conferência missionária Internacional de Willingen em 1952, a ideia da Missio Dei (a missão de Deus) emergiu e chegou ao seu ápice. Significa que a missão é fundamentalmente a obra de Deus no mundo. A teologia da missão não começa com a Igreja e nem mesmo com o Cristo, mas com o Deus Trino [...]. A fonte da missão, portanto, está na própria natureza de Deus", cf. BARTH, K. The Epistle to the Romans. London: Oxford University Press, 1968. p. 330-331. O Deus da revelação cristã é um Deus missionário que sai e vai ao encontro.

${ }^{52}$ Cf. BOSCH, 2002.

${ }^{53}$ Cf. RESTORI, Memore. A Missão no Vaticano II. São Paulo: Paulus, 2015. 
Em resumo, os documentos conciliares do Vaticano II trazem uma visão nova de missão da igreja. Para Suess, "a missiologia como teologia fundamental torna-se núcleo central do Vaticano II"54. Para o autor, dentre os documentos do Concílio que apontam os apelos da missão ad gentes destacam-se: a Dei Verbum, enfocando a revelação de Deus presente em todos os povos, um Deus conosco, que sai e vem ao nosso encontro e nos faz filhos e filhas e nos incumbe com igual missão, a de propagar o amor fraternal, a sermos uma família única, chamada "povo de Deus"; a Lumen Gentium, afirmando que igreja é todo o povo de Deus, que nela não há membros passivos, mas somente ativos, destacando o sacerdócio comum dos fiéis ${ }^{55}$; a Sacrosanctum Concilium (SC), integrando uma liturgia missionária, a ser inculturada nas culturas e na tradição dos povos. ${ }^{56}$ Conforme Suess, Ad Gentes n. 37 afirma que é preciso levar o amor até os confins da terra, numa igreja que se preocupa "com os que estão longe como se fossem seus próprios membros", pois missão significa abertura e solidariedade. A dinâmica do Reino é o pão partilhado com todos na sociedade, não somente com os de nossa casa. Ele afirma que a missão é compreendida como militância para um mundo melhor e que a sua relevância histórica está na "vinculação com o projeto do Reino, que é uma proposta de ruptura com sistemas, lógicas, práticas e mentalidade, sem promessa de perfeição histórica"; "a essência missionária da Igreja está a serviço do Reino"57.

No n. 2 do Decreto Ad Gentes é possível observar que a origem e o fim da missão da igreja é o amor. $\mathrm{O}$ amor leva à abertura para acolher e compartilhar com o outro. O Pai, o Filho e o Espírito, Deus Amor, é o cerne da missão da igreja, o motivo do ser missionário. Deus se revela e o amor se faz presente no meio do povo. ${ }^{58}$

\section{Considerações finais}

A igreja é, por sua natureza, missionária (AG 2), pois nasceu da missão e vive para missão. O Concílio Vaticano II evidenciou a natureza missionária da igreja, que tem como sua razão de ser a missão. O papa João Paulo II afirma que "sem a missão ad gentes, a própria dimensão missionária da Igreja ficaria privada do seu significado fundamental e de seu exemplo de atuação"

A presente abordagem, em um primeiro momento, mostrou o rosto da igreja missionária antes do Concílio, marcada pela perspectiva colonialista, de imposição e implantação da igreja. Entretanto, os padres conciliares, sensíveis ao mal-estar da época, levaram a cabo uma intensa reflexão, que redundou em uma atitude nova em relação à atividade missionária da igreja no mundo. Graças a eles, a partir do Con-

\footnotetext{
54 SUESS, 2007, p. 132.

55 PAULO VI. Constituição Dogmática do Concílio Vaticano II: Lumen Gentium, sobre a Igreja (1964), n. 10, 17.

56 SUESS, 2007, p. 135, citando SC, 65.

57 SUESS, 2007, p. 136.

${ }^{58}$ Dei Verbum, n. 17. In: VATICANO II. Compêndio do Vaticano II: Constituições, decretos e declarações. 29. ed. Petrópolis: Vozes, 2000. Ver também Ad Gentes, n. 2.

59 JOÃO PAULO II. Carta Encíclica do Sumo Pontífice: Redemptoris Missio. 1991. n. 34.
} 
cílio Vaticano II, a igreja redescobriu sua natureza missionária ${ }^{60}$, a serviço do reino de Deus, na promoção da justiça, da paz e da harmonia entre todos os povos. É o que colocamos em destaque no segundo momento da abordagem. Com o Vaticano II, houve uma decidida renovação do modelo de missão da cristandade intransigente e fechada, para uma missão aberta ao diálogo com o mundo, com os povos, as culturas e religiões, com sincera admiração e valorização do outro.

Em suma, o Concílio Vaticano II trouxe uma renovação total na visão e na forma de fazer missão, em especial missão ad gentes, embora ainda longe de ser assumida por todos. Por isso é preciso provocar uma maior e profunda reflexão sobre o verdadeiro significado da missão ad gentes que o Vaticano II nos trouxe. É preciso ir mais a fundo no estudo da verdadeira fonte da missão: a Trindade - o Pai que envia o Filho no Espírito, não para dominar ou impor-se, mas para amar, servir e libertar todos.

\section{Referências}

ANDRADE, Joachin. Novo paradigma da missão na visão antropologica. In: LABONTÉ, G.; ANDRADE, Joachin (Orgs.). Caminho para a missao: fazendo missiologia contextual. Brasília: ABC BSB Gráfica e Editora Ltda, 2008. p. 191-206.

BAKKER, Nicolau J. O conceito de "missão": sua história e seu significado na visão pastoral do Papa Francisco. REB, Petrópolis, ano 74, n. 294, p. 436-452, abr./jun. 2014.

BEAVER, Pierce (Ed.). The Gospel and frontier people. Chicago: The William Carey Library, 1973. p. 369-375.

BEVANS, Steven B.; SCHROEDER, Robert P. Constants in context: A theology of mission for today. Maryknoll, New York: Orbis books, 2004.

BÍBLIA SAGRADA. Bíblia de Jerusalém. São Paulo: Paulinas, 1989.

BOSCH, David. Missão transformadora: mudanças de paradigma na teologia da missão. Trad. Geraldo Korndörfer e Luís M. Sander. São Leopoldo: Sinodal, 2002.

BRIGHENTI, Agenor. Concílio Vaticano II: batalha perdida ou esperança renovada? São Paulo: Paulinas, 2015.

. Em que o Vaticano II mudou a Igreja. São Paulo: Paulinas, 2016.

"A pastoral na vida da Igreja: repensando a missão evangelizadora em tempos de mudança”. In: CNBB-Comissão episcopal para a AnimaçÃo Bíblico-catequética. Brasília, 2012. p. 117-138.

BUONO, Giuseppe. O Vaticano e a missão da Igreja. ZENIT o mundo visto de Roma, 17 out. 2013. Disponível em: <https://pt.zenit.org/articles/o-vaticano-e-a-missao-da-igreja/>. Acesso em: 12 abr. 2017.

CANON BURGESS THE MORATORIUM: The search for self-reliance and authenticity. All Africa Conference of Churches Bulletin, v. VII, n. 3, p. 19-42, 1974.

CHIA. Edmond. De 'Missio ad Gentes' para 'Missio inter Gentes'. In: BEVANS, S. B. (Org.). A century of catholic mission: Roman Catholic Missiology 1910 to the Present. Oxford: Regnum Books International, 2013.

COUTINHO, S. R. Missão no contexto do pluralismo religioso. In: LABONTÉ, G.; ANDRADE, Joachin (Orgs.). Caminho para a missão: fazendo missiologia contextual. Brasília: ABC BSB Gráfica e Editora Ltda, 2008. p. 321-336.

${ }^{60}$ Ad Gentes, n. 2. 
DOCUMENTO 105 DA CNBB. Cristãos leigas e leigos na Igreja e na sociedade. Disponível em: $<$ https://spirandiopadre.wordpress.com/2016/07/16/cristaos-leigas-e-leigos-na-igreja-e-na-sociedade-sal-da-terra-e-luz-do-mundo-mateus-513-14-cnbb-documento-105/>. Acesso em: 02 maio 2017.

LABONTÉ, G.; ANDRADE, Joachin (Orgs.). Caminho para a missao: fazendo missiologia contextual. Brasília: ABC BSB Gráfica e Editora Ltda, 2008.

MAESTRO, Luís M. Missão ‘ad gentes' e globalização: desafio para a Igreja no Brasil. Revista Eclesiástica Brasileira - REB, São Paulo, v. 14, n. 56, p. 87-106, 2006.

PAPA FRANCICO. Exortação apostólica do Sumo Pontífice: Evangelii Gaudium: sobre o anúncio do evangelho no mundo atual. São Paulo: Paulinas, 2013.

PAPA JOÃO PAULO II. Carta Encíclica do Sumo Pontífice: Redemptoris Missio: sobre a validade permanente do mandato missionário. São Paulo: Paulinas, 1991.

PAPA PAULO VI. Decreto do Concílio Vaticano II: Ad Gentes. Sobre a atividade missionária da Igreja (1965). In: Compêndio do Vaticano II. Petrópolis: Vozes, 2000.

. Constituição Dogmática do Concílio Vaticano II: Lumen Gentium, sobre a Igreja (1964). In: Compêndio do Vaticano II. Petrópolis: Vozes, 2000.

Constituição Dogmática do Concílio Vaticano II: Dei Verbum. Sobre a revelação Divina (1965). In: Compêndio do Vaticano II. Petrópolis: Vozes, 2000.

RASCHIETTI, Estevão. Ad Gentes: texto e comentário. São Paulo: Paulinas, 2011.

RESTORI, Memori. A Missão no Vaticano II. São Paulo: Paulus, 2015.

SOUZA, Ney. Contexto e desenvolvimento histórico do Concilio Vaticano II. Revista de Teologia e Cultura, n. 02, p. 1-36, out./nov./dez 2005.

SUESS, Paulo. Introdução à teologia da missão: convocar e enviar: servos e testemunhas do Reino. Petrópolis: Vozes, 2007.

UKPONG, Justin. Contemporary Theological Models of Mission: Analysis and critique. AFER, n. 10, p. 162-164, 1983.

VATICANO II. Compêndio do Vaticano II: Constituições, decretos e declarações. 29. ed. Petrópolis: Vozes, 2000.

VELASCO, Rufino. A Igreja de Jesus: processo histórico da consciência eclesial. Petrópolis: Vozes, 1996.

WIKIPÉDIA, a enciclopédia livre. Aggiornamento. Disponível em: <https://pt.wikipedia.org/ wiki/Aggiornamento>. Acesso em: 02 maio 2017. 